\title{
ІНФОРМАТИВНА НАСИЧЕНІСТЬ ІМЕННИКОВИХ КОМПОЗИТІВ НІМЕЦЬКОЇ МОВИ (НА МАТЕРІАЛ МЕДІА-ТЕКСТІВ)
}

Рись Л. Ф. Інформативна насиченість іменникових композитів німецької мови (на матеріалі медіа-текстів).

У статті проаналізовано можливості вербалізації різного роду інформації в номінативній структурі іменникових композитів (ІК) німецької мови. ІК містять фактуальну (раціональну) та прагматичну (оцінно-експресивну) інформацію про референт. Інформативна насиченість ІК застосовується в медіа-текстах для інформування читача та для формування в нього відповідного ставлення до об'єкта номінації.

Ключові слова: іменниковий композит (IК), інформативність, інформативна насиченість, медіа-текст.

Рысь Л. Ф. Информационная насыщенность именных композитов немецкого языка (на материале медиа-текстов).

В статье проанализированы возможности вербализации разного рода информации в номинативной структуре именных композитов немецкого языка. ИК содержат фактуальную (рациональную) и прагматическую (оценно-экспресивную) информацию о референте. Информационная насыщенность ИК используется в медиатекстах для информирования читателя и формирования у него соответствующего отношения к объекту номинации.

Ключевые слова: именной композит (ИК), информативность, информационная насыщенность, медиа-текст.

Rys L. F. Informational intenseness of noun compounds of German (on the material of media texts).

The article analyses the possibilities of verbalization of different information in the nominal structure of compound nouns of German. Compound nouns contain factual (rational) and pragmatic (evaluative and expressive) information about a referent. Informational intenseness of noun compounds is used in media texts for informing of reader and forming of corresponding attitude toward the object of nomination. media text.

Key words: noun compound (NC), informativeness, informational intenseness,

Створення номінативних одиниць, зокрема й похідних слів, грунтується на взаємодії когнітивної та комунікативної сфер діяльності людини, про взаємозв'язок яких стверджує i М. Л. Макаров: «конструювання когнітивних схем реалізується в дискурсі, який залишається головним модусом i локусом їхнього існування, реалізації i виникнення» $[5$, с. 161]. Фіксація в номінативній одиниці певної виокремленої ознаки позначуваного відображає когнітивні зусилля мовця щодо знаходження засобів (ㄱ Л. Ф. Рись, 2014. 
впливу на адресата, реалізації мовленнєвих інтенцій, які зумовлені участю комунікантів у певному дискурсі.

У процесі аналізу медіа-текстів як мовної реалізації дискурсивного змісту важливу роль відіграє характеристика мовних одиниць різного рівня, котрі розкривають властивості медіа-дискурсу та сприяють реалізації його комунікативної мети. У рамках дослідження медіа-дискурсу можна виокремити вивчення ролі окремих мовних засобів у конструюванні медіа-текстів, зокрема неологізмів, вторинної номінації, мовної гри, політичної метафори. Вибір i використання лексичних одиниць сприяє досягненню максимальної ефективності певного типу дискурсу, втілює в життя певні дискурсивні стратегії й тактики, забезпечує зв'язність, смислову цілісність, інформативність його текстової реалізації та сприяє досягненню інтенцій мовця. Тому дослідження взаємозв'язку дискурсу з його складниками, особливо номінативними одиницями, $є$ перспективним як у плані детальнішого вивчення організації дискурсу, так і у плані дослідження дискурсивної реалізації лексичних структур, у нашому дослідженні - іменникових композитів.

Похідні слова, передусім іменникові композити, володіють значним текстотвірним потенціалом, що забезпечує реалізацію текстово-дискурсивних категорій на структурному, семантичному та прагматичному рівнях, про що свідчать дослідження на матеріалі різних мов (Д. А. Аксельруд, О. Б. Грещук, С. Peschel). Науковці вивчали функціонально-стилістичні та семантико-стилістичні характеристики узуальних та оказіональних композитних одиниць (Л. М. Дембовська, Г. В. Вальчук, Л. А. Кухар), функції ономасіологічної структури композитів англійської мови у формуванні текстово-дискурсивних категорій зв'язності, членування, модальності, адресатності / адресантності, інтерактивності, інтертесктуальності (О. Я. Кресан).

Особливістю іменникових композитів німецької мови ми вважаємо їхню інформативну насиченість, здатність детальніше порівняно 3 іншими словотвірними засобами представити денотат, вербалізуючи у формі словотвірних основ мінімум дві його ознаки (Rennauto, Südfrucht, Zuckergetränk); слугувати позначенням денотативної ситуації (Kurzstreckenflug, Alkoholmissbrauch, Preissteigerung); представити не лише поняттєвий, але й образний компонент вербалізованого концепту у формі порівняння, метафори, метонімії (Ohrwurm, Datenautobahn). Тому актуальним постає питання 
дослідження як інформативної насиченості ІК, так і їхньої можливості сприяти формуванню однієї 3 основних текстово-дискурсивних категорій - інформативності.

У зв'язку з тим, що дискурсивні характеристики іменникових композитів та їхня функціональна взаємодія 3 текстоводискурсивними категоріями на матеріалі німецької мови вивчені ще недостатньо, метою нашої наукової розвідки є аналіз ролі IК у реалізації текстово-дискурсивної категорії інформативності в німецькомовному медіа-дискурсі. Реалізація поставленої мети дослідження передбачає виконання таких основних завдань: виявити i проаналізувати можливості презентації різної інформації у структурі IK, прослідкувати логіко-семантичні відношення між IK та дискурсивним контекстом, їхню роль у формуванні інформативності всього медіа-тексту. Об'єктом дослідження є IK як номінативні, когнітивні та комунікативні одиниці сучасної німецької мови.

Основною функцією ЗМІ $є$ інформування аудиторії про найважливіші події в суспільстві, тиражування та поширення інформації, знань, концептів й образів. Категорія інформативності означає наявність у повідомленні деякої інформації, а також певне співвідношення обсягу (розміру) повідомлення та кількості інформації в ньому. Повідомлення може бути надмірно інформативним, що перешкоджає його сприйманню, та неінформативним, банальним, не містити нової для адресата інформації. Інформативність - це властивість дискурсу передати повідомлення цінне (актуальне, цікаве, потрібне) для адресата.

Під інформацією у вузькому розумінні мають на увазі факти, повідомлення, приписи; у широкому - вираження людської діяльності, яке полягає у зміні кількості та якості інформації, якою володіють учасники діяльності, що приводить до зміни їхньої поведінки [9, с. 40]. Інформація може бути маніфестована в знаковій формі природних мов, а також у невербальних засобах комунікації. I. Р. Гальперін запропонував поняття трьох типів інформації: змістово-фактуальну, змістово-концептуальну та змістово-підтекстову інформацію, зважаючи на те, що багато текстів здатні передавати не лише те, що має буквальну інтерпретацію, але й те, що втягнуто в текст асоціаціями й конотаціями, інколи неусвідомленими [2, с. 25-41].

Стосовно іменникових композитів ми використовуємо терміни «фактуальна інформація» (співвіднесення номінативної структури зі структурою знань про позначуване) та «прагматична» (інформація, 
яка грунтується на асоціативному, образному й емотивно-оцінному наповненні фреймової структури композита), тобто суб'єктивномодальна, що має прагматичне спрямування на вплив та переконання. Когнітивна діяльність людини включає інтерпретацію як фактичної інформації (об'єктивних властивостей предмета чи явища), так і судження про цінність об’єкта й емоційне ставлення суб'єкта мовлення до об'єкта номінації, а саме ці прагматичні фактори виступають складниками семантики композита, що здатні здійснювати вплив на адресата. Оцінний компонент значення $\epsilon$ зазвичай культурно-детермінованим, однак залежить і від особистісних переконань та уявлень індивіда, які підлягають впливу. Експресивна й емотивно-оцінна лексика, з одного боку, апелює до загальнолюдських і національних цінностей, викликаючи необхідну автору реакцію, з іншого, - сама допомагає творити переконання та уявлення адресата, а отже, є важливим засобом впливу. Саме тому нам видається виправданим умовне протиставлення фактуальної (раціональної) і прагматичної (спрямованої на певну реакцію читача) інформації.

Найменшою семантично-інформативною одиницею Й. Рейшер уважає поняття (уявлення, концепт). Пропозиція за допомогою комбінаторики понять здатна через здійснення предикації висловити додаткову нову інформацію про окремий предмет, що було б, однак, неможливим за відсутності інформативності самих понять [10, с. 172].

Інформативність номінативних одиниць пов'язана 3 поняттями «значення» та «смисл». Значення слова розглядається дослідниками як можлива інформація, що «потенційно міститься в окремо взятому слові, залежить від обсягу його змісту, суми ознак, що в сукупності становлять поняття» [3, с. 98]. Під час використання мовної одиниці в мовленні відбувається актуалізація піi значення, слово набуває конкретного смислу. Відповідно, потенційна інформативність слова за взаємодії з контекстом перетворюється в актуальну інформацію.

Як ми вже зазначали, ІК характеризує велика інформативна насиченість (термін А. В. Олянича [6, с. 120]), оскільки IК володіють відносно великою кількістю семантичних ознак, котрі деталізують смислове наповнення номінативної одиниці, уточнюють параметри об'єкта номінації. Така інформативна насиченість корелює 3 точністю, на противагу приблизності найменування. Наприклад, IК FünfZentner-US-Fliegerbombe (sueddeutsche.de, 08.11.2006) містить інформацію про те, що ця бомба $є$ авіаційною, має американське 
походження та масу 5 центнерів (зауважимо, іще культурологічний аспект одного зі складників номінативної одиниці, який полягає в розбіжності у значенні такої одиниці маси як, «центнер»: для українця центнер відповідає 100 кг, для німця - 50 кг). Інформативна насиченість цього композита дає змогу автору використати його в передтексті статті, однак надалі він застосовує еліптичні стосовно нього структури Fünf-Zentner-Bombe, Fliegerbombe, що зумовлено зокрема дією максими Г.-П. Грайса щодо дозування інформації. Адже повторення такого інформативно насиченого композита в ідентифікуючій функції, коли читачеві відомі характеристики позначуваного, є надмірним. Застосування багатокомпонентних IK $\epsilon$ характерним для термінологічних систем, де вони здатні конкретизувати поняття, в однослівній номінації виразити кілька його ознак: Militär-Geländewagen, Wachstumsbeschleunigungsgesetz, Sportanlagenlärmschutz, Bundeskleingartengesetz.

Здатність IК профілювати одну з властивостей об'єкта номінації може бути використана відправником повідомлення для усвідомленої та цілеспрямованої актуалізації певної інформації, що є релевантною ситуації мовлення. Проаналізуємо неологізм Umweltprämie, що слугував найменуванням доплати за утилізацію старого автомобіля за умови купівлі нового, яка проводилася у 2009 році в Німеччині задля того, аби виправити кризову ситуацію, що склалася в автомобільній галузі, та сприяти охороні навколишнього середовища, оскільки нові автомобілі менше забруднюють атмосферу вихлопними газами. В IК Umweltprämie ономасіологічна ознака, виражена першим складником композита, вербалізує взаємозв'язок цієї виплати 3 охороною навколишнього середовища, у той час як інші їі назви (Abwrackprämie, Pkw-Abwrackprämie, Verschrottungsprämie) пов'язують іiі 3 розбором, здачею на лом (старого авто). Тобто ці кореферентні назви вербалізують різні ділянки знання про об’єкт номінації.

Хоч інформативність зазвичай протиставляється експресивності й емоційності, однак, на нашу думку, експресивні та оцінні лексичні одиниці не позбавлені інформативності, навпаки, вони містять інформацію іншого типу - персуазивну. Зважаючи на домінантну спрямованість медіа-дискурсу на формування думки читацької аудиторії, основною комунікативною стратегією в медіа-текстах В. Є. Чернявська визнає персуазивність, під якою розуміє вплив автора усного чи письмового повідомлення на його адресата задля того, щоб переконати його в чомусь, закликати до здійснення чи 
нездійснення певних дій. При цьому механізми персуазивності наділені комплексним характером, оскільки здійснюються в єдності раціонального (аргументативного) й афективно-чуттєвого начал [8, с. 25-35]. Саме так здатні функціонувати IК: поєднувати фактуальну та оцінну інформацію, яка допомагає читачеві визначити місце об'єкта номінації в системі цінностей, сформувати певне ставлення до нього.

IК, іменуючи предмети чи явища, містять інформацію про різнорідні структури знання про ці явища, які були представлені нами у попередніх роботах у вигляді фреймів [7]. Такі структури можуть містити інформацію про кількісні (Zweidrittelgesellschaft, Achtelfinal), якісні (Kleinbild, Warmluft, Bitterschokolade), просторові (Alpenwiese, Polarlicht, Wüstenemirat), темпоральні (Achtundsechziger-Jargon, Nachwendezeit), буттєві / акціональні (Bettelkomponist, Spionagering, Schadstoff) та оцінні параметри позначеного (Ehrengast, Höchstform, Erfolgsmodell). Складники IК можуть виражати також родо-видові (Haifisch, Zinkennase, Schockzustand, Waisenkind, Mordtat) чи партитивні відношення (Elternhaus, Männerhand, Frauenkörper, WallStreet-Häuser), узаємодію чи асоціативні зв'язки об'єкта номінації 3 іншими об'єктами (Froschmann, Monsterauto, Botenstoff, Schrottmode, Butterflymesser). Зазвичай у формальній структурі композита знаходить відображення лише частина фреймової структури знання про об'єкт, однак ця частина профілює важливу для автора інформацію. Решту інформації читач отримує з контексту, або ж вона розглядається як уже відома для нього, а отже, не потребує висвітлення.

ІК здатні інформувати не тільки про ознаки об'єкта, але й представляти певну дію (розгортатися в акціональний фрейм), пропозицію, яка, будучи категорійно переосмисленою як предмет, може бути включена в тексті в іншу пропозицію. Інколи інформативно насичені композити містять у згорнутій формі одночасно дві пропозиції: Organhandel-Verdacht, Steuersenkungsversprechen, Schadenersatzforderung, Selbstmordanschlag. Такі ІК відтворюють окремий позамовний фрагмент дійсності (денотативну ситуацію), профілюють одного 3 iї учасників, їхні властивості чи характер взаємодії. У номінативній структурі ІК може бути представлена сама дія, суб'єкт дії (Herzschlag, Wirtschaftswachstum), предмет дії (Pflichtverletzung, Kaffeegenuss, Polizistenmord), засіб чи інструмент дії (Internetbuchung, Taxifahrt, Raketenbeschuss) та iї часово-просторові 
(Herbsttagung, Olympiasieg, Kaukasus-Konflikt) і якісні характеристики (Festanstellung, Schnelllauf). Невиражені експліцитно компоненти ситуації відновлюються з контексту чи на основі екстралінгвістичних корелятивних зв'язків. Так, наприклад, складники IК Verlustbringer, що слугує предикатною номінацією матері в статті focus.de (Mutti ist die Beste. Wenn sie sich nur um ihre Kinder kümmert, ist sie allerdings ein ausgesprochener Verlustbringer), інформують читача про те, що матері приносять збитки, кому саме ми дізнаємося з тексту статті про великі витрати держави на програму підтримки народжуваності в країні (Niederkunfts-Animationskampagne). Тобто встановлення інших учасників денотативної ситуації можливе на когнітивному рівні на основі дискурсивного контексту.

Варто зауважити, що інформація, яка збирається журналістами, підлягає певній обробці, тому, окрім фактуальної інформації, медіатексти містять суб'єктивно-модальну, що виражає ставлення автора, редакції чи власників видання до описаних фактів. I хоч основними атрибутами публіцистичної інформативності $є$ точність, документалізм, стриманість та офіційність, автору рідко вдається уникнути оцінних висловлювань, що сприяють формуванню певного ставлення до прочитаного в адресата. Такою прагматичною інформативністю володіють IК, що містять асоціативно-образні та емотивно-оцінні складники: Da rettet sie nur ihr Filmstarlächeln, so ein Breitleinwandlächeln, das einen ganzen Kinosaal ausfüllen kann... (sueddeutsche.de, 06.10.2006). Такі композити швидше формують уявлення, образ, ніж інформують читача.

Завдання окремих видів статей - сформувати ставлення до описуваного, виразити його переваги чи недоліки, чому й підпорядковується селекція мовних засобів, як, наприклад, у кінокритиці: Das ist ja das Paradox des Bummbumm-Blockbuster-Kinos, dass es sein Publikum einerseits so behandelt, als leide es unter Aufmerksamkeitsdefizit, andererseits aber nie merkt, wann es genug ist. (faz.net, 01.08.2007). Ставлення автора відчувається і в такому заголовку «Möchtegern-Mutter der Armen», де іронічна номінація відомої співачки Мадонни підсилюється й подальшим насмішкуватим тоном статті: «So aufgeregt war sie nicht mehr, seit sie ihr letztes Paar Gucci-Schuhe kaufte» - die Adoption eines Halbwaisen aus Malawi ist schwieriger, als Madonna erwartet hat (sueddeutsche.de, 16.10.2006). Прочитавши такий заголовок та передтекст до статті про всиновлення африканського хлопчика, читач уже буде налаштований сприймати 
такий учинок як нещирий, спрямований на саморекламу піар-хід.

Окрім того, складниками ІК можуть виступати імена - носії культурної інформації, денотати яких виступають як еталони часу, простору, міри [4, с. 142]. Такі імена мають символічне значення у своїй культурі й, окрім найменування конкретного предмета, вони володіють певним абстрактним значенням, характерним для відповідної культури, за ними стоять культурно специфічні концепти. Так, наприклад, у композиті Kopftuch-Frau перший складник реалізує символічне значення належності до ісламської релігії та культури, й композит передає інформацію не лише про жінку, яка носить хустку, а й про жінку, що сповідує ісламську релігію, через що й з'являється завжди в хустці. У цьому композиті Kopftuch реалізує як своє пряме предметне, так і абстрактне, символічне значення. У наступному контексті: Gegen den Hass der Kemalisten und unter den argwöhnischen Augen der Militär muss er beweisen, dass er kein Exponent der KopftuchFraktion ist, sondern ein Staatsoberhaupt für alle Türken (spiegel.de, 20.08.2007) той же перший складник реалізує лише символічне значення, оскільки йдеться про ісламістську фракцію.

Категорія інформативності корелює 3 конститутивними категоріями тексту, зокрема 3 його формальною зв'язністю та змістовою цілісністю. Така кореляція полягає передусім у побудові рема-тематичних ланцюжків, що відображають співвідношення відомої (теми) й нової (реми) інформації в послідовності пропозицій у дискурсі: Jetzt haben wir aber einen Elite-Arbeitsmarkt. Dieser Arbeitsmarkt, auf dem nur noch Leistungsfähigkeiten eine Chance haben, macht so manchen Arbeitnehmer erst depressiv. (sueddeutsche.de, 16.05.2006). Інший узаємозв'язок інформативності номінативних структур зі зв'язністю тексту полягає у створенні кореферентних ланцюжків, що приписують одному й тому референтові різні характеристики. Можливість по-різному позначати предмети $\epsilon$ наслідком множинності суджень, які можуть бути винесені про об'єкт (особу чи предмет) [1, с. 307]. Такі судження грунтуються на знаннях про об'єкт номінації, можуть відображати діяльність позначуваної особи та іï характеристики. Так, наприклад, у статті в SPIEGEL ONLINE від 24.01.2014 p. Віталія Кличка описують, порівнюючи його колишню спортивну та теперішню політичну діяльності: «Seine Karriere vom Box-Star zum Oppositionsführer war rasant», "Der in zwei Monaten vom Polit-Neuling zum Hoffnungsträger aufgestiegene BoxChampion», водночас автор статті згадує i його зовнішні 
характеристики: der Zwei-Meter-Mann. Як бачимо, найменування у формі IK можуть бути як інформативними, так i образними позначеннями особи (Hoffnungsträger), та вербалізують різні ділянки знання про об'єкт номінації.

ІК виступають як інформативно насичені одиниці, що містять фактуальну та прагматичну інформацію про дискурсивно вагомий референт, здатні представляти певну дію, денотативну ситуацію, містити культурно значиму інформацію. Здатність номінативної структури ІК профілювати одну або й кілька характеристик референта застосовується в медіа-текстах для усвідомленої та цілеспрямованої актуалізації релевантної інформації й формування в адресата відповідного ставлення до об'єкта мовлення. Предметом подальшого дослідження може бути зіставний аналіз функціонування IК у різних типах дискурсу.

\section{Література}

1. Арутюнова Н. Д. Номинация и текст / Н. Д. Арутюнова // Языковая номинация : Виды наименований / под ред. Б. А. Серебренникова. - М. : Наука, 1977. - С. 304-357.

2. Гальперин И. Р. Текст как объект лингвистического исследования / И. Р. Гальперин. - М. : Наука, 1981. - 140 с.

3. Гальперин И. Р. Информативность единиц языка / И. Р. Гальперин // Избранные труды. - М. : Высшая школа, 2005. - С. 7-194.

4. Гудков Д. Б. Теория и практика межкультурной коммуникации / Дмитрий Борисович Гудков. - М. : ИТДГК «Гнозис», 2003. - 288 с.

5. Макаров М. Л. Основы теории дискурса / Михаил Львович Макаров. - М. : ИТДГК «Гнозис», 2003. $-280 \mathrm{c}$.

6. Олянич А. В. Презентационная теория дискурса : [монографія] / А. В. Олянич. - М. : ИТДГК «Гнозис», 2007. -407 с.

7. Рись Л. Ф. Фреймова семантика субстантивних композитів / Л. Ф. Рись // Науковий вісник Волин. держ. ун-ту ім. Лесі Українки. Серія : Філологічні науки. 2007. - № 4. - С. 96-102.

8. Чернявская В. Е. Дискурс власти и власть дискурса : проблемы речевого воздействия : [учеб. пособ.] / Валерия Евгеньевна Чернявская. - М. : Флинта ; Наука, 2006. - 136 с.

9. Шевченко И. С. Историческая динамика прагматики предложения : английское вопросительное предложение 16-20 вв. : [монография] / И. С. Шевченко. - Харьков : Константа. - 1998. - 168 с.

10. Reischer J. Zeichen. Information. Kommunikation: Analyse und Synthese des Zeichens und Informationsbegriffs [Електронний pecypc] / Jürgen Reischer. - Режим доступу : http://epub.uni-regensburg.de/10483/1/ZeichenInfoKomm.pdf (05.04.2014) 